\title{
COMMENTS
}

\section{Beyond CTS: A Limited Defense of State Tender Off er Disclosure Requirements}

Only within the last two decades has securities regulation extended to tender offers. In 1968, Congress passed the Williams Act in an attempt to protect shareholders faced with tender offers. State legislatures have enacted regulations as well, in most cases rather similar to those of the Williams Act. All these regulations impose disclosure requirements on the offeror, substantive requirements on the terms of the offer, and general antifraud prohibitions in connection with the offer. Where the entire federal and state regulatory schemes have been brought into effect simultaneously, courts generally have held the state statutes unconstitutional under the supremacy and commerce clauses.

This term, in CTS Corporation v. Dynamics Corporation of America, ${ }^{1}$ the Supreme Court upheld an Indiana statute that severely restricted the ability of offerors to gain control of a target corporation. Under the Indiana law, any time a person acquires shares that push her total holdings over a "control share" thresh-

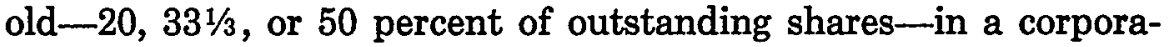
tion subject to the statute, she must gain approval of both the target's board of directors and a majority of nonacquiring and nonmanagement shares in order to vote her shares. ${ }^{2}$ In upholding the statute, the Court ruled that a state, through its power to regulate shareholder voting rules, may regulate takeovers of corporations that are both chartered by the state and have substantial assets in the state. ${ }^{3}$ It is likely that many states will take advantage

1107 S.Ct. 1637 (1987).

2 Management can delay the approval vote for up to fifty days. Ind. Code § 23-1-427(b) (Supp. 1986). Thus, without the requisite approval, shares acquired in a tender offer are useless for asserting control over the corporation.

${ }^{3}$ For a corporation to be subject to the Indiana act, it must have substantial assets in Indiana as well as either (1) more than $10 \%$ of its shareholders resident in Indiana; or (2) 
of CTS to regulate takeovers of in-state corporations in a similar fashion to the Indiana law-through requiring that acquisitions be approved by a majority of shareholders. ${ }^{4}$

Nevertheless, statutes that regulate takeovers by placing direct restrictions on the acquisition of shares will remain important. First, most current state antitakeover statutes directly restrict the acquisition of shares, and it may be a while before states can revise their laws to take advantage of CTS. Second, some states that regulate the acquisition of shares may not wish to restrict shareholders' traditional ability to vote their shares freely. ${ }^{5}$ Third, there may be some corporations, both large and small, with insufficient assets in their state of incorporation to be subject to the type of regulation approved by the Court in CTS. ${ }^{6}$ Finally, CTS explicitly authorizes regulation only by the state chartering a target corporation. Thus, a state will be unable to use $C T S$-sanctioned laws to govern takeovers of out-of-state corporations that have significant assets or numbers of shares or shareholders within the state. This may prove the most substantial limitation on state's powers under CTS. For example, a great many corporations are chartered in Delaware while their principal assets and shareholders are elsewhere, often concentrated in one state. ${ }^{7}$

In the only Supreme Court case on the issue of direct state regulation of share acquisition, Edgar v. MITE Corp., ${ }^{8}$ a majority of the justices found that the Illinois Business Takeover Statute ${ }^{9}$ imposed an impermissible though indirect burden on interstate commerce. A plurality of the Court further found that the Illinois statute placed an impermissible direct burden on commerce and also violated the supremacy clause. In spite of the ruling in MITE,

more than $10 \%$ of its shares owned by Indiana residents. Ind. Code $\S 23-1-42-4$ (a).

4 The noted takeover specialist, Martin Lipton, predicts that thirty to forty states eventually will eventually adopt statutes modeled after the Indiana act. Justices Back State Curbs on Takeovers, Wall St. J. 3, col. 1 (Apr. 22, 1987).

s The Wall Street Journal reports that there probably will be a substantial fight in Delaware, the jurisdiction currently most important to corporate law, over whether to adopt a statute similar to that of Indiana. Id. at 18, col. 1.

- See CTS, 107 S.Ct. at 1652 ("the Indiana Act applies only to corporations that have a substantial number of shareholders in Indiana").

7 Even so, states may feel that they have an interest in controlling the takeover of outof-state corporations with significant local interests. For example, the North Carolina legislature approved a measure that would require out-of-state companies with major North Carolina interests to obtain the approval of 90 percent of their shares in order to go through with a takeover. See also N.C. Gen. Stat. $\$ \$ 55-80$ et seq. Robert J. Cole, Burlington Charges Paine Webber Leak, N.Y. Times 30, col. 5 (nat'l ed. Apr. 30, 1987).

457 U.S. 624 (1982).

- Ill. Rev. Stat. ch. 121 1/2, I 137.51 (1979). 
however, the Court's recent decisions in Schreiber v. Burlington Northern, Inc. ${ }^{10}$ (holding that the Williams Act is no more than a disclosure statute) and CTS (limiting the preemptive power of the Williams Act) call into question the ability of existing federal tender offer regulations to displace state law requirements.

This comment focuses particularly on the situation with regard to target companies not required to register under section 12 of the Securities Exchange Act. The Williams Act's antifraud provisions apply to all takeovers; its disclosure provisions apply only to registered companies, that is, those whose asset values or number of shareholders are above certain minimums. When these thresholds are not met, and thus only the antifraud provisions of the Williams Act are activated, the issue is more difficult because there is a wider scope for state regulation.

This comment focuses on the constitutionality of direct state regulation of share acquisition in these narrow circumstances. It first analyzes both federal and state regulation of tender offers. Next, it discusses the implications of the Supreme Court's MITE, Schreiber, and CTS decisions. It then discusses state regulation in light of both the supremacy and the commerce clauses. It first concludes that state regulation of share acquisition through tender offers that goes beyond the federal scheme does not violate the supremacy clause. It then argues that state antifraud regulations nonetheless violate the commerce clause as an impermissible burden on interstate commerce. However, the comment concludes that the disclosure requirements of these state statutes should still stand because they are constitutional in themselves and are severable from the unconstitutional provisions.

\section{Tender Offer Legislation}

The Williams Act ${ }^{11}$ was passed in 1968 in order to fill a perceived gap in the coverage provided by federal securities laws. ${ }^{12}$ Before the act, when one corporation sought to gain control of another through either a stock-for-stock exchange or a proxy contest, federal regulations required disclosure of that information believed to be necessary to informed shareholder decisions about the op-

10472 U.S. 1 (1985).

${ }^{11} 15$ U.S.C. $\S \S 78 \mathrm{~m}(\mathrm{~d}),(\mathrm{e}), 78 \mathrm{n}(\mathrm{d})$, (e), (f) (1982), amending the Securities Exchange Act of 1934, 15 U.S.C. $\$ \S 78 \mathrm{a}-78 \mathrm{kk}$ (1982) ("Exchange Act"), by adding sections 13(d), 13(e), 14(d), 14(e), and 14(f).

${ }_{12}$ Disclosure of Corporate Equity Ownership, H.R. Rep. No. 1711, 90th Cong., 2d Sess. 3 (1968). 
tions available to them. ${ }^{13}$ The cash tender offer, however, had become an increasingly popular method of corporate acquisition from the early 1960 s onward, and it was subject to no such regulations. ${ }^{14}$ The Williams Act changed this.

The legislative history of the Williams Act reveals a sensitivity to the potentially varied effects of tender offers on shareholders. On the one hand, some offers were felt to "serve a useful purpose in providing a check on entrenched but inefficient management."15 But Congress also conceded that the improvement of management was not the ultimate goal of all offerors. ${ }^{16}$ The act was "designed to require full and fair disclosure for the benefit of investors while at the same time providing the offeror and management equal opportunity to fairly present their case," ${ }^{17}$ while ensuring that these requirements were not so burdensome as to effectively preclude the possibility of the offer's success. ${ }^{18}$

Most state tender offer legislation, it appears, is also designed principally to protect shareholders. ${ }^{19}$ However, the state laws are not explicitly concerned with preserving equal opportunity for both target and bidder to pursue their separate goals. An examination of the differences between the provisions of the federal and state statutes is necessary to determine whether the variance is sufficient to warrant invalidation of the state acts.

\section{A. The Disclosure Requirements of the Williams Act}

Section 14(d) sets out both a list of filing requirements for

13 Because they involve the issuance of securities, stock-for-stock exchanges were, and still are, regulated by the Securities Act of 1933, 15 U.S.C. $\$ \S 77 \mathrm{a}-77 \mathrm{aa}$ (1982) ("Securities Act'); proxy contests are covered by $\$ 13(\mathrm{a})$-(c) of the Exchange Act, 15 U.S.C. \$\$ 77a-77aa. See generally H.R. Rep. No. 1711 (cited in note 12).

14 See H.R. Rep. No. 1171 at 2 (cited in note 12).

15 Id. at 4.

18 Id.

17 Id. See also 113 Cong. Rec. 854 (daily ed. Jan 18, 1967) (statement of Sen. Williams) ("I have taken extreme care with this legislation to balance the scales equally to protect the legitimate interests of the corporation, management, and shareholders without unduly impeding cash takeover bids. Every effort has been made to avoid tipping the balance of regulatory burden in favor of management or in favor of the offeror.").

18 The most widely recognized way in which tender offer laws can prevent the success of a takeover bid is to require delays and thus provide opportunities for incumbent management to respond to the offer. The Supreme Court recognized this as a significant concern in MITE, 457 U.S. at $637-39$, as have numerous commentators. See, e.g., Donald C. Langevoort, State Tender-Offer Legislation: Interests, Effects and Political Competency, 62 Cornell L. Rev. 213, 238 (1977); Diane S. Wilner and Craig A. Landy, The Tender Trap: State Takeover Statutes and Their Constitutionality, 45 Fordham L. Rev. 1, 9-10 (1976).

19 See, e.g., 70 Pa. Stat. Ann. $\S 72$ (Purdon Supp. 1985); 6 Va. Code $§ 13.1-528$ (1985). 
those making tender offers, and several substantive requirements regarding the terms of these offers. The scope of this section is clear: only those offers for shares of a class of securities registered under section 12 of the Exchange Act ${ }^{20}$ and made by persons or entities who, upon consummation of the offer, would become owners of more than 5 percent of that class are covered by the 14(d) provisions. $^{21}$

The filings required by section 14 (d) must be made by the time the tender offer has been either published or sent to shareholders. ${ }^{22}$ The information to be disclosed is essentially that mandated by section 13(d) of the Williams Act: (1) the "background and identity" of the purchasers; (2) the "source and amount of funds" to be used in effecting the acquisition; (3) the plans of the purchasers regarding any significant changes in the corporate structure of the target; (4) the number of shares that the offeror owns or has the right to acquire; and (5) any "contracts, arrangements, or undertakings" entered into by the purchaser regarding the target's shares. ${ }^{23}$ Additionally, all solicitation materials must be filed prior to the time of their publication, and all information filed with the SEC also must be sent to the target company before it is published or sent to shareholders. ${ }^{24}$

Section 14(d) also imposes three substantive limitations on the terms of the offer itself. First, offerees who have tendered their shares must be allowed to withdraw them within fifteen days of, and after sixty days from, the commencement of the offer. ${ }^{25}$ Second, if within ten days from the time the offer is made, more shares have been tendered than the offeror is willing to accept, she must purchase all shares tendered on a pro rata basis. ${ }^{26}$ Third, if the offeror increases the price to be paid for tendered shares after

${ }^{20} 15$ U.S.C. $\$ 78(1)$. This provision requires all issuers of stock that affect interstate commerce or are engaged in interstate commerce to register their securities if those securities are held by 500 or more shareholders or if the issuer has assets exceeding $\$ 1$ million. The minimum asset requirement for registration was raised to $\$ 3$ million by Exchange Act Rule 12g-1, 17 C.F.R. § $240.12 \mathrm{~g}-1$ (1986). Several types of securities, including those listed on and registered with a national securities exchange, and those securities issued by investment companies registered pursuant to $\S 8$ of the Investment Company Act of 1940, are exempt from these requirements.

${ }^{21} 15$ U.S.C. $\$ 78 \mathrm{n}(\mathrm{d})(1)(1982)$.

22 Id.

${ }^{23}$ Id. $\S 78 \mathrm{~m}(\mathrm{~d})(1)(\mathrm{A})$-(E) (providing for disclosure of information by a holder of 5 percent or more of the shares of any class of outstanding equity security).

24 Id. $\S 78 \mathrm{n}(\mathrm{d})(1)$.

${ }^{25} 17$ C.F.R. $\S 240.14 d-7$ (1986), enacted pursuant to Exchange Act $\S 14(d)(5), 15$ U.S.C. $\S 78 \mathrm{n}(\mathrm{d})(5)(1982)$.

${ }^{28} 15$ U.S.C. $\$ 78 \mathrm{n}(\mathrm{d})(6)$. 
the offer has been initiated, she must pay the higher price for all tendered shares-even those tendered before the price increase. ${ }^{27}$

\section{B. The Antifraud Provisions of the Williams Act}

Section 14(e) prohibits all "fraudulent, deceptive or manipulative acts or practices" connected with tender offers, including untrue statements and misleading omissions of material facts. ${ }^{28}$ Pursuant to this section, the SEC has enacted a regulation requiring that all offers be held open for at least twenty business days, and at least ten business days after any increase in the consideration offered. ${ }^{28}$ The SEC also has promulgated an "all-holders rule," requiring that tender offers be open to all holders of a given class of security. ${ }^{30}$

The scope of section 14(e) is the subject of some debate. By its own terms, the section is applicable to "any tender offer," some contend that this language was a mistake and that those who drafted and voted on the legislation supposed that it, like section 14(d), applied only to tender offers for registered securities.

Commentators offer several arguments to support this limited reading of the scope of $14(\mathrm{e}) .^{32}$ First, the "any tender offer" language of section 14(e) does not explicitly include unregistered securities, while the language of section $10(\mathrm{~b})$ of the Securities Exchange Act of 1934, for example, states that its provisions cover "any security registered on a national securities exchange or any security not so registered." The clear language of $10(\mathrm{~b})$ could have been easily duplicated; that it was not suggests that the broad language of 14(e) was not intended to be all-inclusive. Second, the legislative history of the Williams Act often draws an analogy to federal regulation of proxy contests, which applies only to registered securities. ${ }^{34} \mathrm{~A}$ third argument against a broad reading of

${ }^{27}$ Id. $\S 78 \mathrm{n}(\mathrm{d})(7)$.

${ }^{28}$ Id. $\& 78 \mathrm{n}(\mathrm{e})$.

28 17 C.F.R. \& 240.14e-1 (1986).

so See Rule 14d-10, 17 C.F.R. $\$ 240.14$ d-10 (1986). The Commission promulgated this rule pursuant to, among others, section 14(e). SEC Exch. Act Release No. 23421 (July 11, 1986), corrected in Exch. Act Release No. 23421B (Sept. 4, 1986), reprinted in (Current) Fed. Sec. L. Rep. (CCH) I 84,016 (1986).

s1 15 U.S.C. \& 78n(e).

32 For an argument supporting such an interpretation of 14(e), see Alfred F. Conard, Tender Offer Fraud: The Secret Meaning of Subsection 14(e), 40 Bus. Law. 87 (1984).

ss 15 U.S.C. $\& 78 \mathrm{j}(\mathrm{b})$ (1982).

36 See H.R. Rep. No. 1711 at 3 (cited in note 12); 113 Cong Rec. at S24,665 (daily ed. Aug. 30, 1967) (statement of Sen. Williams) ("This legislation is patterned on the present law and the regulations which govern proxy contests."). 
14(e) points to the absurd consequences of extending its scope to the literal limits: foreign tender offers, exclusively intrastate tender offers, and tender offers for shares in closely held corporations all would fall within the "any tender offer" language. Professor Conard offers further support that 14(e) was not intended to extend to tender offers for unregistered securities, pointing to several items from the legislative history of the Williams Act indicating that each of its sections applied only to tender offers for registered securities. ${ }^{35}$

None of these arguments is particularly compelling. In the first place, the language of the statute is clear. An inference of implied limitations cannot be justified by a lack of phrasing precisely identical to other portions of the act that purport to advance the same purpose. Further, there is a significant distinction between saying that one type of legislation is patterned after another and saying that the two are alike in every respect. In addition, despite the supposedly "absurd" consequences resulting from a broad reading of $14(\mathrm{e})$, Congress has yet to amend the language of the statute. Moreover, there is no reason why tender offers for unregistered securities should not be subject to the same antifraud regulations as those for registered securities. Finally, the pieces of legislative history Professor Conard points to do not discuss the scope of 14(e) in particular, but are instead general statements about the bill as a whole. This does not compel a construction of 14(e) clearly contrary to its language.

Both the SEC and the courts have favored the more expansive

3540 Bus. Law. at 89 (cited in note 32). See 114 Cong. Rec. 21,483 (daily ed. July 15, 1968) (statement of Rep. Keith) ("I state further there is a proviso which makes this not apply to the corporation which does not qualify under section $12(\mathrm{~g})$ of the Securities Act; namely, a corporation with less than $\$ 1$ million and fewer than 500 shareholders."); H.R. Rep No. 1711 at 6 (cited in note 12) ("The revision of the amended subsection 13(e)(1) to provide . . . that the issuer here being discussed is the same as in the other subsections of the bill, namely the issuer of an equity security of a class which is registered pursuant to section 12 of the act.") (emphasis added); Hearings on S.510 Before the Subcomm. on Securities of the Senate Comm. on Banking and Currency, 90th Cong., 1st Sess. 249-50 (1967) (letter from Milton Cohen to Sen. Williams) ("Either as a further matter within the scope of the Commission's rule-making power or as a separate statutory provision, there should also be, of course, a prohibition against false or misleading statements of material facts or omissions of material facts necessary to make statements not misleading, in connection with any tender offer within the scope of the section.") (emphasis added); H.R. Rep. No. 1655, 91st Cong., 2d Sess. 7 (1970) (SEC memorandum) ("[The Williams Act] consisted of amendments to sections 13 and 14 of the Securities Exchange Act of 1934 ('the act') and provides for disclosure with respect to substantial acquisitions of securities registered under the act and in connection with tender offers for such securities, together with protections against fraudulent activities in connection therewith.") (emphasis added). 
reading of $14(\mathrm{e})$. In one no-action letter, the SEC stated that "the provisions of Section $14(\mathrm{e})$, the antifraud portion of the Williams Act, are applicable with respect to all tender offers, requests or invitations for tenders without regard to the class or kind of security involved."38 This judgment has since been reiterated in several of the Commission's releases ${ }^{37}$ and has been adopted in a number of judicial decisions. ${ }^{38}$ Thus, both the courts and the agency created by and entrusted with the enforcement of the act of which section $14(\mathrm{e})$ is a part agree that $14(\mathrm{e})$ should be read literally to apply to all tender offers, regardless of whether the target securities are registered.

\section{State Tender Offer Laws}

At present, twenty-nine states impose some sort of direct regulation on the acquisition of shares in tender offers for corporations connected in any one of a number of ways to these states. ${ }^{30}$ The scope of most of these statutes is substantially similar. None of the statutes applies to an offer unless: (1) the offer, if successful, would result in the purchaser's ownership of a certain percentage of any single class of the outstanding stock of the target; and (2) there is

se Henry Heide, Inc., 1972-1973 (Transfer Binder) Fed. Sec. L. Rep. (CCH) I 78,838 at 81,836 (May 31, 1972).

${ }^{37}$ SEC Release No. 33-6158, 1979-1980 (Transfer Binder) Fed. Sec. L. Rep. (CCH) If 82,373 at 82,581 n.7 (Nov. 29, 1979); SEC Release No. 33-6159, 1979-1980 (Transfer Binder) Fed. Sec. L. Rep. (CCH) i 82,374 at 82,604 n.15 (Nov. 29, 1979).

${ }^{38}$ See, e.g., L.P. Acquisition Co. v. Tyson, 772 F.2d 201, 208 (6th Cir. 1985); E.H.I. of Florida, Inc. v. Ins. Co. of North America, 652 F.2d 310, 315 (3d Cir. 1981) ("Unlike the proxy regulations of section 14(a) and the disclosure requirements of 14(d), the anti-fraud proscriptions contained in section 14(e) apply to any class of security.").

so Alaska Stat. \$§ 45.57.010-45.57.120 (1986); Ark. Stat. Ann. §§ 67-1264 to 67-1264.14 (1980); Conn. Gen. Stat. Ann. $\$ \S 36-456$ to 36-469 (West 1981 and Supp. 1986); 8 Del. Code Ann. $\S 203$ (West 1981 and Supp. 1986); Hawaii Rev. Stat. $\S \S 417 \mathrm{E}-1$ to 417E-11 (1985); Idaho Code $\S \S 30-1501$ to 30-1513 (Michie Supp. 1986); Ind. Code Ann. $\S \S 23-2-3.1-0.5$ to 23-2-3.1-11 (Burns 1984); Iowa Code Ann. $\S \S 502.102,502.211-502.2156$ (West Supp. 1986); Kan. Stat. Ann. $\S \S 17-1276$ to 17-1285 (1981 and Supp. 1985); La. Rev. Stat. Ann. §§ 51:1500-51:1512 (West Supp. 1986); Mass. Ann. Laws ch. 110c, §§ 1-13 (Law Coop. 1985); Mich. Comp. Laws Ann. §§ 451.901-451.917 (West Supp. 1986); Minn. Stat. Ann. §§ 80B.0180B.13 (West 1986); Miss. Code. Ann. §§ 75-72-101 to 75-72-121 (Supp. 1986); Mo. Ann. Stat. $\S ~ 409.500-409.531$ (Vernon Supp. 1987); Neb. Rev. Stat. $\S \S 21-2418$ to 21-2430 (1983); Nev. Rev. Stat. $\S \S 78.376$ to 78.3778 (1985); N.H. Rev. Stat. Ann. $\S$ 421-A:1 to 421-A:16 (1983 and Supp. 1986); N.J. Stat. Ann. \$§ 49:5-1 to 49:5-19 (West Supp. 1986); N.Y. Bus. Corp. Law §§ 1600-1613 (McKinney 1986); N.C. Gen. Stat. §§ 78B-1 to 78B-11 (1985); Ohio Rev. Code Ann. § 1707.041 (1985); 71 Okla. Stat. Ann. \$§ 431-450 (West Supp. 1987); 70 Pa. Stat. Ann. §§ 71-85 (Purdon Supp. 1986); S.C. Code Ann. §§ 35-2-10 to 35-2-130 (Law Coop. Supp. 1985); S.D. Codified Laws Ann. §§ 47-32-1 to 47-32-48 (1983); Tenn. Code Ann. §§ 485-102 to 48-5-112 (1984); Va. Code $\S \S 13.1-528$ to 13.1-541 (1985); Wis. Stat. Ann. §§ 552.01552.25 (West Supp. 1986). 
some connection between the target corporation and the involved state. The statutes are roughly split as to whether the tender offer must result in 5 percent or 10 percent ownership in order for the restrictions to apply. ${ }^{40}$ The most common test for determining whether there are sufficient connections between the involved corporation and the regulating state considers whether the corporation is either organized under the laws of the state or has both its principal place of business and substantial assets in the state. ${ }^{.1}$ Many state statutes exempt from coverage issuer offers for their own shares ("self-tenders") 42 and tender offers approved by incumbent management.43

Like the Williams Act, most current state takeover laws both require disclosure of information and restrict the terms of the offers themselves. While the information to be disclosed is for the most part the same as that required by $14(\mathrm{~d}),{ }^{44}$ the timing of the disclosure often differs from that under 14(d). A large number of states will not allow a tender offer to commence unless a filing has been made with the appropriate state authorities some days or weeks beforehand. ${ }^{45}$ Additionally, most states allow the state official charged with the enforcement of the statute to delay the offer by holding a hearing, if deemed necessary, to determine whether the requirements imposed by the statute have been met. ${ }^{46}$

With regard to restrictions on the terms of the offer, state

40 Thirteen statutes require 5 percent ownership. See, e.g., 8 Del. Code Ann. § 203(c)(2); N.Y. Bus. Corp. Law § 1601(a); $70 \mathrm{~Pa}$. Stat. Ann. § 73. Fifteen states require 10 percent ownership. See, e.g., Conn. Gen. Stat. Ann. § 36-457(h); Ohio Rev. Code Ann. $\S 1707.041(\mathrm{~A})(1) ; \mathrm{Va}$. Code $\S 13.1-529(\mathrm{~b})(\mathrm{i})$. One state requires ownership of 20 percent before its statute goes into effect. See Kan. Stat. Ann. \& 17-1276(a).

4 See, e.g., Mass. Ann. Laws ch. 110c, § 1; Mich. Comp. Laws Ann. § 451.904(1). Some states have added to these tests a third factor: they allow application of the statute if a certain percentage of the outstanding shares of the target corporation are held by state residents. See, e.g., S.C. Code Ann. $\$ 35-2-20(5)$ (d) (5 percent). Some states, however, have made efforts to limit the scope of their statutes. See, e.g., Minn. Stat. Ann. $\S 80$ B.01(9) (applying only to targets having at least 20 percent of their securities held by state residents).

12 See, e.g., Conn. Gen. Stat. Ann. § 36-457 (h)(6); 8 Del. Code Ann. title 8, § 203(c)(3); $70 \mathrm{~Pa}$. Stat. Ann. \& 73.

13 See, e.g., Mass. Ann. Laws ch. 110c, § 1; Ohio Rev. Code Ann. § 1707.041(A)(1)(d); Va. Code § 13.1-529(b)(v).

4 See, e.g., 8 Del. Code Ann. § 203(a)(1); N.Y. Bus. Corp. Law § 1603; Va. Code § 13.1$531(b)$.

${ }^{45}$ See, e.g., N.J. Stat. Ann. § 49.5-3(a) (West Supp. 1986) (filing must be twenty days prior to commencement of offer); N.C. Gen. Stat. $\$ 78 \mathrm{~B}-4$ (a) (filing must be thirty days prior to commencement of offer).

16 See, e.g., Mich. Comp. Laws Ann. § 451.907; N.Y. Bus. Corp. Law § 1604; Ohio Rev. Code Ann. § 1707.041(B)(4). 
statutes are also in many respects similar to $14(\mathrm{~d})$ and $14(\mathrm{e})$. It is in the way in which some of these requirements are to be met-most particularly, with regard to matters of timing - that the state and federal schemes differ most importantly. Many states require that offers remain open for periods of time longer than the federally mandated twenty days. ${ }^{17}$ Also, in many instances the withdrawal provisions differ from those in 14(d).48

Many state statutes contain provisions not found in the Williams Act. They commonly require that all offers extend to state residents as well as nonresidents and that the terms of the offer be substantially the same for residents and nonresidents. ${ }^{49} \mathrm{~A}$ small number of statutes contain provisions allowing those portions of the statute found unconstitutional or otherwise invalid to be severed from the remainder of the statute without invalidating the whole. ${ }^{\text {so }}$

\section{MITE, SCHREIBER, CTS, AND}

the Substance of the Winliams Act

\section{A. MITE}

The first Supreme Court case to deal directly with the conflict between state and federal regulation of share acquisition through tender offers is Edgar v. MITE Corp., ${ }^{\text {s1 }}$ where the Court held that the Illinois Business Takeover Act ${ }^{52}$ violated the commerce clause by placing an excessive indirect burden on interstate commerce. Four justices, a plurality of the Court, held that the Illinois act also violated the commerce clause by placing a direct burden on interstate commerce, ${ }^{5 s}$ and three justices thought that the state law was preempted by the Williams Act. ${ }^{54}$

In holding that the Illinois act placed an impermissible indirect burden on commerce, the Court noted that the statute's de-

47 See, e.g., Alaska Stat. $\$ 45.57 .010$ (1) (twenty-one to thirty-five-day minimum open provision); Mich. Comp. Laws Ann. § 451.905(2) (sixty-day minimum open period).

${ }^{48}$ See, e.g., S.C. Code Ann. $\$ 35-2-80(3)$ (withdrawal allowed any time within twenty days and after thirty-five days from the commencement of the offer).

49 See, e.g., Mass. Ann. Laws ch. 110c, § 7; Ohio Rev. Code Ann. § 1707.041(C).

so Kan. Stat. Ann. § 17-1284; Mass. Ann. Laws ch. 110c, § 13; N.H. Rev. Stat. Ann. § 421-A:16; N.J. Stat. Ann. § 49:5-18; N.C. Gen. Stat. § 78B-11; N.Y. Bus. Corp. Law § 1611.

31457 U.S. 624, 643-46 (1982).

s2 Ill. Rev. Stat. ch. 1211/2, II 137.51.

ss 457 U.S. at $641-43$.

s4 Id. at 631-39. In addition, three justices believed the case was moot, id. at 655-64 (Marshall, dissenting), and one believed that it failed to present a justiciable controversy, id. at 664-67 (Rehnquist, dissenting). 
clared purpose, the protection of shareholders, did not justify the regulation because the act affected shareholders outside of Illinois and because the Williams Act provided all the protection shareholders needed. Furthermore, the Court indicated that the delay made possible by the Illinois act actually might harm shareholders in that it would allow management to defeat value-increasing tender offers. ${ }^{\mathrm{s}}$ Implicit in this view is that shareholders benefit from the ability to receive and freely evaluate tender offers from bidders for corporate control..$^{88}$

The four justices who ruled that the Illinois act placed a direct burden on commerce noted that the state law by its terms could have applied to tender offers in which none of the shareholders of the target company were residents of Illinois. In addition, were such regulations to be adopted across the country, "interstate commerce in securities generated by tender offers would be thoroughly stifled."s7

Finally, three justices took the position that the Williams Act preempted the Illinois act. They acknowledged that the Securities Exchange Act of 1934, to which the Williams Act is an amendment, allows the states to regulate securities so long as such regulations do not conflict with the Exchange Act itself. ${ }^{58}$ They further recognized that, as is the case with most state laws regulating tender offers, it would be possible for an offeror to comply with both the Illinois act and the Williams Act. Thus, the main question was whether the state statute substantially frustrated the objectives of the federal law. The justices found that the Williams Act has two goals: shareholder protection and a careful balancing of the interests of management, offerors, and targets. "Congress sought to protect the investor not only by furnishing him with the necessary information but also by witholding from management ... . any undue advantage that could frustrate the exercise of an informed choice."59 Those parts of the Illinois act that allowed target management an advantage not found in the Williams Act were preempted by the substantive force behind the federal statute. This argument, however, was not adopted by the full Court, and was undercut without dissent just three years later.

ss Id. at 644.

so See Frank H. Easterbrook and Daniel R. Fischel, The Proper Role of a Target's Management in Responding to a Tender Offer, 94 Harv. L. Rev. 1161, 1174-82 (1981).

${ }^{67}$ MITE, 457 U.S. at 642.

ss Id. at 630-31, citing Exchange Act $\S 28(a), 15$ U.S.C. $\S 78 \mathrm{bb}(a)$.

so 457 U.S. at 631-34. 


\section{B. Schreiber}

In Schreiber v. Burlington Northern, Inc., the Court held that misrepresentation or nondisclosure is a necessary element of a violation of section 14(e) of the Exchange Act. ${ }^{.0}$ In so deciding, the Court concluded that the only purpose of the antifraud provisions of the Williams Act is to ensure full disclosure, ${ }^{61}$ presumably of the information required by section 14(d) of the act. Accordingly, section 14(e) simply creates a cause of action for conduct that is defined elsewhere.

The effect of Schreiber on MITE is substantially to undermine the earlier decision: if there is no substance to the Williams Act beyond the requirement of disclosure, it is difficult to see how the act can have any preemptive force whatsoever ${ }^{62}$ True, Congress may have wished that no state action affect the balance of power in a contest for corporate control; however, many facets of state corporate law do just that. In any case, Schreiber casts great doubt on the preemptive capability of the Williams Act.

\section{CTS}

In upholding the Indiana Control Share Acquisition Statute, the Court in CTS did not reject MITE's commerce clause analysis. Rather, it held that states have such great interests in the governance of the corporations their laws create that so long as they do not directly discriminate against out-of-state shareholders, states may control the way shareholders may-or may not-govern their corporations. ${ }^{63}$ Also, the Court neither discussed Schreiber nor rejected the MITE plurality's argument for preemption. ${ }^{64}$ However,

so 472 U.S. 1, 2 (1985).

61 Id. at 11-12.

22 In fact, one might ask how a provision with no substance beyond disclosure requirements can be used as authority for the numerous SEC rules governing the substantive functioning of tender offers. See, e.g., Exchange Act Rule 14e-1, 17 C.F.R. § 240.14e-1 (1986) (requiring that a tender offer be open for twenty business days). While the Court in Schreiber noted that section 14(e) mandates that the SEC "shall . . . by rules and regulations define, and prescribe means reasonably designed to prevent, such acts and practices" that involve material misrepresentation and nondisclosure, 472 U.S. at n.11 (quoting $\S 14(\mathrm{e})$ ), much of the conduct regulated by the commission in relation to tender offers seems totally unrelated to deception. For example, compare Unocal Corp. v. Pickens, 608 F.Supp. 1081 (C.D. Cal. 1985) (discriminatory self-tender does not violate the antifraud provisions) with the new "all-holders" rule, Exchange Act Rule 14d-10, 17 C.F.R. $\$ 240.14 d-10$ (1986) (tender offers must be open to all holders of a given class of security). It is hard to see how this latter requirement prevents deception.

os 107 S.Ct. at 1650-52.

ot Id. at 1645 ("[W]e are not bound by [the plurality's] reasoning. We need not ques- 
the Court in CTS seemed to limit the preemptive power of the Williams Act to cases either where management is given an advantage in controlling the requirements of tender offers or where the delay required by the state regulation is so long as to make impossible a successful legal tender offer. Finally, the Court noted that were the Williams Act to preempt all facets of corporate law that gave management an upper hand in corporate control fights, then numerous provisions of many states' corporate laws would be unconstitutional-a result that the Court was not willing to contemplate. $^{65}$ Fundamentally, the distinction between the MITE plurality and the CTS Court is that a restriction on the ability to vote a share is not the same as a restriction on the ability to buy or sell it: states may define the bundle of rights embodied in share ownership, but they may not directly restrict alienation of those rights. ${ }^{68}$

Further, the CTS decision points toward a limitation on the power of chartering states to regulate the takeover of corporations they create. The Court in CTS noted with favor that "the Indiana Act applies only to corporations that have a substantial number of shareholders in Indiana," rules of corporate governance to restrict takeovers is conditioned upon the existence of local benefits from doing so. This is important for two reasons. First, it means that unless enough states-or, at least, enough of the principal chartering states-adopt the sort of law approved by CTS, there will remain a significant number of potential target corporations that are not covered by state antitakeover regulations. Second, the Court's emphasis on the protection of local shareholders suggests that in some circumstances states may place small burdens on interstate commerce-in particular, direct restrictions on the acquisition of shares through tender offers-in order to achieve this goal.

tion that reasoning, however, because we believe the Indiana Act passes muster even under the broad interpretation of . . . MITE.").

os Id. at 1647-48.

6o The restrictions in the Indiana statute upheld in CTS, because they are contingent on transfer, are indirect restrictions on the alienation of shares-although the CTS Court never called them that. See id. at 4486 (White, dissenting). While the distinction between direct and indirect restrictions may seem thin, it has been accorded respect in the courts. See note 84 and accompanying text.

6r 107 S.Ct. at 1652. 


\section{Constitutional Analysis of State Takeover Statutes}

\section{A. The Supremacy Clause}

The supremacy clause provides that the Constitution "and the Laws of the United States which shall be made in Pursuance thereof . . . shall be the supreme Law of the Land." sary corollary of this provision that state laws that conflict or interfere with federal laws must give way. Over the years the Court has developed three rough categories of state legislation invalidated under this clause. The first category includes state legislation involving areas deemed to have been "occupied" by the federal government: that is, those areas in which the Court has determined that the federal government intended to be the sole regulatory force. The decision that a field is occupied, however, is one that the Court will reach only with reluctance. As the Court noted in Florida Avocado Growers v. Paul, "[t]he principle to be derived from our decisions is that federal regulation of a field of commerce should not be deemed preemptive of state regulatory power in the absence of persuasive reasons-either that the nature of the regulated subject permits no other conclusion, or that the Congress has unmistakably so ordained." 69

Second, state legislation violates the supremacy clause if it so directly conflicts with a federal statute that "compliance with both federal and state regulations is a physical impossibility." "7o Third, even when compliance with both statutes is possible, state legislation will be struck down if it "stands as an obstacle to the accomplishment and execution of the full purposes and objectives of Congress." "71

None of the common provisions of state antitakeover legislation violate the supremacy clause. As to state disclosure requirements, section 14(d) does not apply to unregistered companies, and therefore these requirements could not be said to be preempted for that class of companies. But even the antifraud and other provisions of section $14(\mathrm{e})$, which do apply to unregistered companies, do not preempt state antitakeover legislation. Congress did not intend that the federal government be the sole regulatory force in the field of securities. As the Court emphasized in MITE, the Se-

${ }^{88}$ U.S. Const. art. VI, cl. 2.

B9 373 U.S. 132, 142 (1963).

to Id. at 142-43.

71 Hines v. Davidowitz, 312 U.S. 52, 67 (1941). See also California Federal Sav. \& Loan Ass'n v. Guerra, 107 S.Ct. 683, 689 (1987) (noting "sole task" of Court is to determine the intent of Congress, and reviewing supremacy clause doctrine). 
curities Exchange Act of 1934 states clearly that "[n]othing in this title shall affect the jurisdiction of the securities commission (or any agency or officer performing like functions) of any State over any security or any person insofar as it does not conflict with the provisions of this title or the rules and regulations thereunder."72 State statutes therefore are not preempted by an express congressional desire to occupy the field.

Also, compliance with both federal and state law is not a "physical impossibility." Certainly no state statute allows fraud. Indeed, most states have antifraud provisions largely identical in substance to $14(e) .^{73}$ Direct conflict could exist only between state laws and the regulations enacted by the SEC pursuant to 14(e). The Supreme Court has noted:

It has been established in a variety of contexts that properly promulgated, substantive agency regulations have the "force and effect of law." This doctrine is so well established that agency regulations implementing federal statutes have been held to preempt state law under the Supremacy Clause. ${ }^{74}$

However, the SEC's regulations and state takeover laws do not contradict each other. While the SEC's requirement that tender offers stay open for a minimum of twenty days differs from a number of the minimum open requirements in state statutes, ${ }^{75}$ compliance with both is not impossible. If these conflicting standards are indeed only minimums, then offerors may simply comply with the longer of the two time periods, and thus satisfy the requirements of both.

But state regulation also must not interfere with the realization of the congressional purpose behind the federal statute. A longer minimum period may undercut congressional intent to leave longer open periods to the discretion of the offeror. Recall that the purpose of the Williams Act is to allow investors to make informed responses to tender offers without creating an advantage for either target or bidder management. Some evidence shows that, in Congress's view, the twenty-day minimum open period precisely strikes this careful balance. In a 1979 release, the SEC indicated

${ }^{2}$ Exchange Act $\S 28(a), 15$ U.S.C. $\$ 78 \mathrm{bb}(\mathrm{a})$, cited in MTTE, 457 U.S. at 631 . See also CTS, 107 S.Ct. at 1653 (Scalia, concurring).

${ }_{7 s}$ See, e.g., N.Y. Bus. Corp. Law $\$ 1609 ; 71$ Okla. Stat. Ann. § 455; Tenn. Code Ann. § 48-5-106.

74 Chrysler Corp. v. Brown, 441 U.S. 281, 295-96 (1979). See also Paul v. United States, 371 U.S. 245, 250-55 (1963); Free v. Bland, 369 U.S. 663, 668 (1962).

${ }^{25}$ See note 47 . 
that it was considering a thirty-day minimum open period. ${ }^{76}$ Later, the Commission stated that it found "persuasive the views of the commentators who indicated that a minimum period of thirty business days is unnecessarily long." N7 Nonetheless, in CTS the Court stated that a possible delay of fifty days-ten days short of the maximum time a tender offer can remain open under the Williams Act-would not be too long. ${ }^{78}$ Thus, it appears that a minimum open period that is longer than twenty days does not upset congressional design.

Also, since Sckreiber suggests that section $14(e)$ has no substantive force other than to prohibit fraudulent disclosure, the main function of the regulations enacted pursuant to that section simply cannot be to "equalize" the tender offer process. ${ }^{79}$ And as the Court noted in CTS, numerous aspects of state law-such as those mandating staggered elections for boards of directors and supermajority requirements for mergers-tend to favor management in any contest for corporate control, whether or not that contest is conducted through a tender offer. The Court in CTS rejected any possible federalization of corporate law. ${ }^{\mathbf{8 0}}$

\section{B. The Commerce Clause}

1. The burdens on commerce from antitakeover legislation. To the extent that they impede tender offers, state laws directly regulating the acquisition of shares probably place an impermissible burden on interstate commerce. While Congress did not intend to occupy the field of securities regulation, the scope of state legislation in this area cannot be absolute. It is limited by the commerce clause of the Constitution, which gives to Congress the power "[t]o regulate Commerce . . . among the several States." ${ }^{\text {81 }}$ It

76 SEC Release No. 33-6022, 1979 (Transfer Binder) Fed. Sec. L. Rep. (CCH) II 81,935 at 81,236 (Feb. 5, 1979).

77 SEC Release No. $33-6158$ at 82,595 (cited in note 37 ).

${ }^{78}$ CTS, 107 S.Ct. at 1647 ("We cannot say that a delay within that congressionally determined period is unreasonable.").

79 Schreiber, 472 U.S. at 9, notes that Congress intended to strike a balance, but it does not follow that Congress meant that balance to be maintained by the states.

8o See text at note 65. See also Dynamics Corp. of America v. CTS Corp., 805 F.2d 705, 718 (7th Cir. 1986) ("Dynamics II"), in which the court regarded as frivolous arguments that state rules of corporate law authorizing a board of directors to adopt a "flip in" poison pill defense to a takeover attempt were unconstitutional. Ironically, the same panel had earlier held that the Indiana Control Share Acquisition Act was unconstitutional under both the supremacy and the commerce clauses. Dynamics Corp. of America v. CTS, 794 F.2d 250, 263-64 (7th Cir. 1986) ("Dynamics I"), rev'd by CTS, 107 S.Ct. at 1637.

82 U.S. Const. art. I, § 8, cl. 3. 
has long been recognized that this grant of power contains an implicit limitation on states' power to enact legislation that interferes with interstate commerce, even when no conflicting federal statute exists. $^{82}$

Although the extent of this limitation has been the subject of lengthy debate, certain general principles are discernible. In Pike v. Bruce Church, Inc., the Court offered these guidelines:

Where the [state] statute regulates evenhandedly to effectuate a legitimate local public interest, and its effects on interstate commerce are only incidental, it will be upheld unless the burden imposed on such commerce is clearly excessive in relation to the putative local benefits. ${ }^{83}$

The Court's approval of "incidental" effects on commerce seems indistinguishable from its intermittent approval of "indirect" effects of state legislation on commerce. ${ }^{84}$ The "direct/indirect" test, however, has proved to be of little use. As the Court itself has pointed out, "[t]he line of division between direct and indirect restraints of commerce involves in its marking a reference to considerations of degree." fects collapses into the balancing test set out in the final clause of the Pike formulation, which prohibits state burdens on commerce that are "clearly excessive" in relation to the purported benefits of the legislation imposing the burden.

After Pike, four factors are important in determining the validity of a state statute under the commerce clause. ${ }^{86}$ First, the state statute must be "evenhanded"- that is, it must extend identically to residents and nonresidents. ${ }^{87}$ Second, the state interest

${ }^{82}$ See, e.g., MITE, 457 U.S. at 640; Lewis v. BT Investment Managers, Inc., 447 U.S. 27, 35 (1980); Hughes v. Oklahoma, 441 U.S. 322, 326 (1979); Philadelphia v. New Jersey, 437 U.S. 617, 623 (1978); A. \& P. Tea Co. v. Cottrell, 424 U.S. 366, 370-71 (1976).

ss 397 U.S. 137, 142 (1970), citing Huron Cement Co. v. Detroit, 362 U.S. 440, 443 (1960).

84 See, e.g., Shafer v. Farmers Grain Co., 268 U.S. 188, 199 (1925); Smith v. Alabama, 124 U.S. 465, 482 (1888).

ss Baldwin v. G.A.F. Seelig, 294 U.S. 511, 525 (1935).

- It is somewhat misleading to categorize the varied approaches to commerce clause analysis as a series of "tests." As Professor Tribe said of commerce clause jurisprudence, "these doctrines ... suggest that the Supreme Court has preserved them with an eye to their discretionary application in order to prevent what appear to be instances of intolerable local or state interference with interstate markets." Laurence H. Tribe, American Constitutional Law 343 (1978).

${ }^{87}$ See, e.g., Raymond Motor Transportation, Inc. v. Rice, 434 U.S. 429, 446-47 (1978) (although not decisive, exceptions in state statute benefiting primarily local concerns "undermine the assumption that the State's own political processes will act as a check on local 
must be "legitimate," or an appropriate state concern.8 ${ }^{88}$ Third, the local benefits that the statute purportedly advances must outweigh the burden imposed upon interstate commerce; ${ }^{89}$ and finally, the state statute must be the least intrusive means available for achieving these local benefits. ${ }^{90}$

State takeover regulations often are not evenhanded. The most acute example of discrimination is the exemption for self-tenders. ${ }^{91}$ While the imposition of different standards for the target-which must have at least some connection to the state-and the bidder has never served as the sole basis for the invalidation of a state statute, it "tends to undermine [the state's] justification for the burdens the statute imposes on interstate commerce." ${ }^{.92}$ A second, somewhat less common, type of statutory provision that imposes discriminatory regulations is that which exempts "friendly" tender offers-that is, those approved by the target board-from statutory coverage. ${ }^{93}$ Such provisions undermine the purported justification of shareholder protection because-as is also the case with the self-tender exception-they substitute the judgment of the target corporation for that of the shareholder.

The protection of shareholders is a valid state concern. ${ }^{94}$ Just as the federal government seeks to ensure that shareholders' decisions are made with adequate knowledge and without undue time pressure, so may the states help local investors in this way. One type of provision clearly tailored to aid local shareholders is a requirement that tender offers be made to residents as well as nonresidents on substantially the same terms.95 More problematic,

regulations that unduly burden interstate commerce"); Hunt v. Washington Apple Advertising Comm'n, 432 U.S. 333, 350-52 (1977) (requirement that containers of imported apples contain either all or no USDA-grade produce necessitates repackaging that results in artificially higher costs for out-of-state growers).

${ }^{88}$ See, e.g., Minnesota v. Clover Leaf Creamery Co., 449 U.S. 456, 471 (1981) ("environmental protection and resource conservation" are legitimate local concerns); S.C. State Hwy. Dept. v. Barnwell Bros., 303 U.S. 177, 187 (1938) ("Few subjects of state regulation are so peculiarly of local concern as is the use of state highways.").

${ }^{80}$ See, e.g., Hunt, 432 U.S. at 350; Southern Pacific Co. v. Arizona, 325 U.S. 761, 770-71 (1945).

${ }^{\circ}$ See, e.g., Hughes, 441 U.S. at 336; Dean Milk Co. v. Madison, 340 U.S. 349, 354-56 (1951).

91 See note 42 and accompanying text.

${ }^{22}$ MITE, 457 U.S. at 644.

${ }^{93}$ See note 43.

See, e.g., MITE, 457 U.S. at 644; Great Western United Corp. v. Kidwell, 577 F.2d 1256, 1283 (5th Cir. 1978), rev'd on other grounds as Leroy v. Great Western United Corp., 443 U.S. 173 (1979).

${ }^{95}$ See note 49 . 
however, are state statutes that could apply to transactions between two nonresidents, at least where the corporations in which they hold shares are nonresidents. ${ }^{96}$

States also enact tender offer legislation in order to preserve the various local benefits arising from the presence of a corporate headquarters or other facility within the state. This goal has been regarded as legitimate by most courts, with the Fifth Circuit noting that "a corporation can influence local lifestyle through such means as charitable contributions or civil involvement and the depth of its commitment to issues such as pollution control or job safety." While it is no doubt in a state's interest to keep within its borders the economic and intangible benefits that responsible corporations provide, such protectionism seems to be precisely what the commerce clause was intended to prevent. ${ }^{88}$ In sum, while the protection of local shareholders is indeed a legitimate local concern, it is at least arguable that keeping corporations within the state is not.

The next line of inquiry is whether the burdens that these state statutes impose on interstate commerce are clearly excessive in relation to their putative local benefits. While shareholder protection is a legitimate local benefit from state statutes, state disclosure requirements may not promote it. Some courts have suggested that these requirements, to the extent they exceed federal specifications, may provide shareholders with so much information that they are confused rather than enlightened. ${ }^{99}$ Also, since section 14(e) of the Williams Act applies to all tender offers, no statemandated disclosure may be fraudulent or misleading. Furthermore, any state regulation-even if it is merely a disclosure requirement-that goes beyond section $14(\mathrm{~d})$ 's requirements makes a bid for corporate control more expensive and may place too great a

96 MITE's statement on this point, see 457 U.S. at 644, must be limited in light of the Court's recent qualification in CTS, 107 S.Ct. at 1651, that a state "has no interest in protecting nonresident shareholders of non-resident corporations" (emphasis in original).

${ }^{87}$ Kidwell, 577 F.2d at 1282-83. See also MITE, 457 U.S. at 646 n.* (Powell, concurring in part).

os See, e.g., Pike, 397 U.S. 137 (holding unconstitutional a state statute that would have required the packing of cantaloupes in state and was specifically aimed at ending a common practice of having the fruit shipped elsewhere for that purpose). Cases disallowing states from enacting statutes restricting the export of certain scarce resources are analogous. See, e.g., Hughes, 441 U.S. 322 (Oklahoma statute prohibiting export of minnows, a natural resource of the state).

" National City Lines, Inc. v. LLC Corp., 687 F.2d 1122, 1131 (8th Cir. 1982); MITE Corp. v. Dixon, 633 F.2d 486, 500 (7th Cir. 1980), aff'd by MTTE, 457 U.S. at 624; Kidwell, 577 F.2d at 1285. 
burden on shareholders, both in and out of state, who have a federally recognized interest in receiving tender offers.

State takeover statutes impose significant burdens on interstate commerce in several ways. First, economic inequality results when nonnegotiated bids are subject to statutory regulations while target self-tenders and management-approved bids are not. Also, some states regulate transactions between parties entirely unconnected with the state, and some limit shareholders' ability to sell their stock at the highest available price by disallowing or fatally delaying certain tender offers. ${ }^{100}$

The burden that such state statutes place on interstate commerce is systemic. Tender offers may be severely discouraged by the uncertain success and potentially high costs associated with offers made for shares of a company located in a state with a takeover statute. ${ }^{101}$ These impediments may reduce economic efficiency. Deterring potential offers and disallowing some initiated offers hinders what MITE found to be an important function of tender offers: "[t]he reallocation of economic resources to their highest valued use, a process which can improve efficiency and competition." 102

The literature on tender offers is extensive and varied; however, most economists and economically oriented lawyers agree that on the whole, target shareholders benefit from tender offers. ${ }^{103}$ Furthermore, even in those cases where resistance to a tender offer benefits the target's shareholders, ${ }^{104}$ this comes at a cost. The offeror's shareholders lose to the same extent that the target's shareholders benefit and overall, fewer tender offers will occur, which harms all shareholders in the long run. ${ }^{105}$ In addition, the danger exists, as noted by the plurality in $M I T E$, that restrictive state laws will stifle the entire interstate market for corporate control. ${ }^{108}$

${ }^{100}$ See, e.g., MITE, 457 U.S. at 643; Televest, Inc. v. Bradshaw, 697 F.2d 576, 580 (4th Cir. 1983). Again, CTS noted that a restriction on the ability to vote a share is not the same as a restriction on its sale or purchase. 107 S.Ct. at 1652.

101 Televest, 697 F.2d at 580.

102457 U.S. at 643.

${ }^{103}$ For an article by scholars in the forefront of empirical work on tender offers, see Michael Bradley, Anand Desai, and E. Han Kim, The Rationale Behind Interfirm Tender Offers: Information or Synergy?, 11 J. Fin. Econ. 183 (1983).

${ }^{104}$ See, e.g., Lucian A. Bebchuk, The Case for Facilitating Competing Tender Offers, 95 Harv. L. Rev. 1028 (1982).

${ }^{10 s}$ See, e.g., Frank H. Easterbrook and Daniel R. Fischel, Auctions and Sunk Costs in Tender Offers, 35 Stan. L. Rev. 1 (1982). For a recent judicial discussion of the economics of tender offers, see Dynamics I, 794 F.2d at 253-54.

${ }^{108}$ MITE, 457 U.S. at 642; Dynamics I, 794 F.2d at 264 ("an interstate, indeed international, market that the State . . . is not authorized to opt out of"). 
To the extent that tender offers are hindered, incumbent management operates without an important check on performance. ${ }^{107} \mathrm{Al}$ though CTS does seem to question the economic desirability of tender offers, the basis of that decision is that a state's interest in regulating the voting rights of shares in the corporations it creates more than outweighs any possible benefits to interstate commerce from tender offers. ${ }^{108}$

Finally, even if the interest in keeping corporate headquarters within the state is legitimate under the commerce clause, tender offer legislation is an excessively discriminatory means of protecting this interest. Some of the advantages accruing from the civic responsibility of local corporations could be achieved through state legislative health and safety regulations as well as state tax incentives to encourage community support and charitable contributions. ${ }^{109}$ The availability of these approaches reduces the state's need to burden interstate commerce through tender offer regulation.

2. The special case of state disclosure requirements. The unnecessary burdens caused by state antitakeover statutes, when considered in situations where the disclosure requirements of section 14(d) are in effect, have moved courts to resolve the balancing of state versus interstate interests against the states. ${ }^{110}$ State-mandated disclosure requirements, however, are another story. These are permissible under the commerce clause, at least with regard to unregistered companies, because the federal disclosure requirements of section 14(d) do not reach these companies, and because disclosure in general places a less onerous burden on the offeror than do other provisions of antitakeover laws.

Only one court has considered the constitutional issues in these narrow circumstances. In L. P. Acquisition Co. v. Tyson, the Sixth Circuit acknowledged the burdens that the Michigan TakeOver Offers Act ${ }^{111}$ placed on interstate commerce, but the court nevertheless found that the state interests in protecting both local shareholders and non-shareholding residents outweighed these burdens. ${ }^{112}$ This result seems correct. In the first place, it is unreal-

${ }^{107}$ MITE, 457 U.S. at 643.

108107 S.Ct. at 1652.

108 Kidwell, 577 F.2d at 1286.

110 MITE, 457 U.S. 624; Cardiff Acquisitions, Inc. v. Hatch, 751 F.2d 906 (8th Cir. 1984); Mesa Petroleum, 715 F.2d 1425; Televest, 697 F.2d 576; Martin-Marietta, 690 F.2d 558; National City Lines, 687 F.2d 1122; Kidwell, 577 F.2d 1256.

11 Mich. Comp. Laws Ann. $\$ \$ 451.901-451.917$ (West Supp. 1986).

112772 F.2d 201, 207 (6th Cir. 1985). The statute was struck down, however, as a violation of the supremacy clause. Id. at 209. 
istic to contend that shareholders will be confused rather than aided by information additional to that mandated by the Williams Act. As a preliminary matter, most statutory disclosure requirements do not exceed those of section 14(d), but rather are largely similar to them. ${ }^{113}$ One state statute has already been upheld on these grounds. ${ }^{114}$ More to the point, it appears highly likely that any investor astute enough to derive useful information about the projected market value of a share of stock from disclosures required by section 14 (d) will be able to do the same if additional information is provided.

Even if shareholders are perplexed by some of the information required under some state statutes, that confusion may be a small price to pay for the benefits arising from state requirements to disclose useful information in the absence of any overlapping federal requirements. With no disclosure requirements, shareholders may be forced to make hasty investment decisions with virtually no knowledge of the offeror's background, intentions regarding the target, or financing arrangements. This lack of information could cause shareholders to forego other sale opportunities while tendering their stock to an offeror whose financing is inadequate to fund the entire deal.

Further, the information disclosed to target shareholders may be more valuable in the case of smaller, largely local targets than when the target is a large national or multinational corporation. Shares may be tendered to an offeror who intends to liquidate assets of the target corporation when the target could be a significant employer in the area where the shareholder lives, or indeed even be the shareholder's own employer. The investor may find herself unknowingly aiding the transfer of a local corporation into the hands of management unresponsive to community needs and desires.

Lastly, whatever the burdens imposed by such legislation on interstate commerce, they are probably less significant in situations where 14(d) does not apply. Either the corporations involved have fewer assets, or their stock is held by fewer shareholders than targets covered by 14(d). Thus, both in terms of the number of dollars affected and the number of individuals affected, the impediment to the free flow of commerce is not as severe.

${ }^{113}$ See note 44 and accompanying text.

${ }^{114}$ Cardiff, 751 F.2d at 912, upholding Minn. Stat. Ann. $\$ \S 80$ B.01-80B.13 (West Supp. 1986). 
It is important to note, however, that while the cost to bidders of disclosure requirements may be less than the cost and uncertainty created by antifraud regulations and restrictions on the terms of the offer itself, disclosure requirements nonetheless may have a disproportionate effect on smaller tender offers. Because the target firms are smaller, the profits the offeror can expect from a successful bid will likely also be smaller. If the cost of compliance with disclosure requirements does not fall at least in proportion to the size of the takeover involved, disclosure costs (like other relatively fixed costs of undertaking any tender offer) will discourage offers for smaller firms more than offers for larger firms. Although disproportionate effects on smaller firms may be worrisome, no empirical evidence shows them to be significant. Further, the courts have rejected commerce clause challenges to the disclosure requirements of state "blue sky" securities laws ${ }^{115}$-laws that present the same problem.

Given that shareholders of unregistered companies are able to benefit from section 14(e), which sets out both antifraud and substantive rules for tender offers, a state needs only disclosure requirements to protect its shareholders in the event of a tender offer for an unregistered company. There is seldom an acceptable justification for removing corporate assets from the interstate market for control. ${ }^{116}$

\section{SEVERABILITY}

It seems odd, however, to conclude that the state antitakeover statutes are constitutional only when the Williams Act's disclosure or substantive requirements do not apply. In these circumstances, invalidation of the only means of shareholder protection may be more troubling than delaying and discouraging tender offers. Indeed, in deciding a case involving a claim for fraud under both 14(e) and Rule 10b-6, the Supreme Court found the congressional concern for neutrality as to targets and bidders to be of clearly secondary importance:

Congress was indeed committed to a policy of neutrality in contests for control, but its policy of evenhandedness does not go ... to the purpose of the legislation. . . . Neutrality is, rather, but one characteristic of legislation directed toward a

116 See, for example, Hall v. Geiger-Jones Co., 242 U.S. 539 (1917).

${ }^{116}$ See MITE, 457 U.S. at 644 . Again, after CTS, a restriction on voting a share does not remove the asset represented by the share from commerce. 
different purpose-the protection of investors. ${ }^{117}$

To invalidate an entire disclosure statute because one of its provisions is problematic would undermine Congress's intent to provide disclosure.

The doctrine of severability provides one way of avoiding this dilemma. In appropriate instances, the unconstitutional portion of a statute can be excised, leaving the remainder unaffected. After severance of the unconstitutional sections from state takeover statutes, the investor could enjoy essentially the same protection whether or not $14(d)$ applies. Where the federal law does not extend, state laws can fill the void.

The criteria for allowing severability are fairly well-settled and argue for its use in state tender offer statutes. The focus is primarily on legislative intent, and the Court has indicated that there should be a presumption that statutes are severable:

Unless it is evident that the legislature would not have enacted those provisions which are within its power, independently of that which is not, the invalid part may be dropped if what is left is fully operative as a law. ${ }^{118}$

The unconstitutional provisions of a state tender offer statute could be severed from its disclosure provisions without rendering the disclosure rules "inoperative as law." None of the state statutes indicate that any provision was intended to be dependent on any other. Further, there is no reason that enforcement of only the disclosure requirements of any state statute would present an illogical or ineffective response to the concerns that either explicitly or implicitly gave rise to their creation. In short, such statutes could and should remain operative.

With regard to the intent of the state legislatures that enacted these statutes, it is unlikely that they would have refused to approve independently each of the remaining portions. Indeed, a few

117 Piper v. Chris-Craft Industries, 430 U.S. 1, 29 (1977).

11 Champlin Rfg. Co. v. Commission of Oklahoma, 286 U.S. 210, 234 (1932). See Regan v. Time, Inc., 468 S.Ct. 641, 653 (1984) (Champlin followed); INS v. Chadha, 462 U.S. 919 , 934 (1983) (presumption of severability); Buckley v. Valeo, 424 U.S. 1, 108-09 (1976) (Champlin followed). It should be noted that in Regan and Buckley the statutes under consideration were federal, and in Chadha, federal regulations were at issue. The Champlin decision, however, involved the severing of a state statute. Because the later decisions made no mention of this difference, it is reasonable to assume that the distinction is of no import and thus that the rules regarding severability of state statutes are no different from those regarding federal statutes. 
states have expressly allowed for severability. ${ }^{119}$ As to the others, it is unlikely that one section containing a minimum open period requirement for tender offers would have been considered so indispensable by the legislature that enacted it that the disclosure provisions would not have been passed in its absence; enforcement of the disclosure provisions still serves the purpose of investor protection professed by most of the states enacting these provisions. It is certainly not "evident" that these truncated statutes would not have been approved.

Thus, it seems both appropriate and desirable to apply the doctrine of severability to preserve the disclosure requirements when other parts of state takeover statutes are found unconstitutional. This results not only in the achievement of the primary goals of both state and federal legislation, but also in the extension of protection to investors not otherwise covered by the Williams Act.

\section{Conclusion}

Although CTS recognizes states' power to regulate takeovers of corporations they charter, this power is of no use to states in controlling takeovers of out-of-state corporations with substantial local interests. Further, a chartering state's power to regulate takeovers might be conditioned on other state interests: if the corporation the state creates has no significant assets, number of shareholders, or concentration of shares within the state, CTS may not apply.

These interstices are particularly problematic when a target corporation is not covered by the disclosure provisions of the Williams Act. In situations where tender offers are subject to only the requirements of section $14(\mathrm{e})$ of the Williams Act, unlike those in which both 14(d) and 14(e) apply, target shareholders need not be left without protection. While state restrictions on the terms of the offer are unconstitutional because they burden the interstate market for corporate control by aiding incumbent management, the doctrine of severability should be used to excise only those provi-

11 See note 50 and accompanying text. 
sions of the state legislation. Shareholders should still be protected by the state disclosure laws that, in the absence of the protection afforded by section 14(d), may provide beneficial information to shareholders.

Steven Gitelman 